\title{
PHYCOLOGICAL OBSERVATIONS- XIV : ACROCYSTIS NANA ZANARDINI, A NEW ALGAL RECORD FOR THE PHILIPPINES
}

\section{$\operatorname{AUTHOR(S):~}$}

Cordero, Paciente A.

\section{CITATION:}

Cordero, Paciente A.. PHYCOLOGICAL OBSERVATIONS-XIV : ACROCYSTIS NANA

ZANARDINI, A NEW ALGAL RECORD FOR THE PHILIPPINES. PUBLICATIONS OF THE SETO MARINE BIOLOGICAL LABORATORY 1981, 26(1-3): 171-175

ISSUE DATE:

1981-03-30

URL:

http://hdl.handle.net/2433/176016

RIGHT: 


\title{
PHYCOLOGIGAL OBSERVATIONS - XIV: ACROCYSTIS NANA ZANARDINI, A NEW ALGAL RECORD FOR THE PHILIPPINES ${ }^{1)}$
}

\author{
Paciente A. Cordero, Jr. \\ Division of Botany, Philippine National Museum, Manila
}

With Text-figures $1-2$

\begin{abstract}
A red marine alga, Acrocystis nana Zanardini (Rhodomelaceac, Rhodophyceae), collected from Calapan, Oriental Mindoro approximately $13.5^{\circ} \mathrm{N}$ and $121.1^{\circ} \mathrm{E}$, is herein described and reported for the first time from the Philippines.
\end{abstract}

\section{Introduction}

In August 1980 a fieldwork was conducted in Calapan, Oriental Mindoro (Fig. 1), by the present investigator and his graduate students enrolled in Advanced Phycology, University of Santo Tomas (UST). In the course of the field-work, there were few interesting marine algae collected. Among the highly prized algal specimens was Acrocystis nana Zanardini, collected by Mrs. Lolita J. Bulalacao, Biology Doctoral student at UST and Faculty Member of the Philippine Normal College. This rare, tiny and colonial rhodomelaceous alga was found growing on rocks exposed at low tide in association with Bostrychia tenella (Vahl) J. Agardh.

In the Philippines, the family Rhodomelaceae is well represented by the genera Acanthophora, Amansia, Bostrychia, Chondria, Digenea, Herposiphonia, Laurencia, Leveillea, Neurymenia, Polysiphonia, Tolypiocladia, and Vidalia. These genera appeared in the taxonomic treatise of Velasquez et al., 1971; Trono 1974; Saito 1969; Reyes, 1971; Menez, 1961 ; Domantay, 1961; Cordero, 1977, etc.

From the neighboring countries of the Philippines, Acrocystis nana was earlier reported by Okamura (1907) using the 1902 collections from Amakusa Island, Japan. Later reports from Japan were those of Segawa (1956) and Chihara (1970). Only Dawson's (1954) report of $A$. nana from Vietnam stands closest to the Philippines. Earlier, though, Weber van-Bosse (1923) included $A$. nana in her account of the marine algae gathered during the Dutch Siboga Expedition.

The presence of $A$. nana in the Philippine waters is most expected considering the proximity of the type locality, which is Borneo, and the fact that the plant's geogra-

1) Part of an on-going project entitled "New and Noteworthy Philippine Marine Algae," tunded by the Philippine National Museum.

Publ. Seto Mar. Biol. Lab., XXVI (1/3), 171-175, 1981. （Article 9) 
phical distribution is confined to the Indo-Pacific region.

However, this is the initial report that documents the existence of $A$. nana in the Philippine waters.

\section{Study Area}

Calapan, Oriental Mindoro is barely 2-21/2 hours by commercial boat from Batangas Province. The collecting areas included Punta Lasareto and Barangay Balete about 5-6 kilometers apart. The entire coast of Calapan is washed by the waters of the South China Sea that cuts through the Batangas Channel. The water is relatively rough during the rainy months.

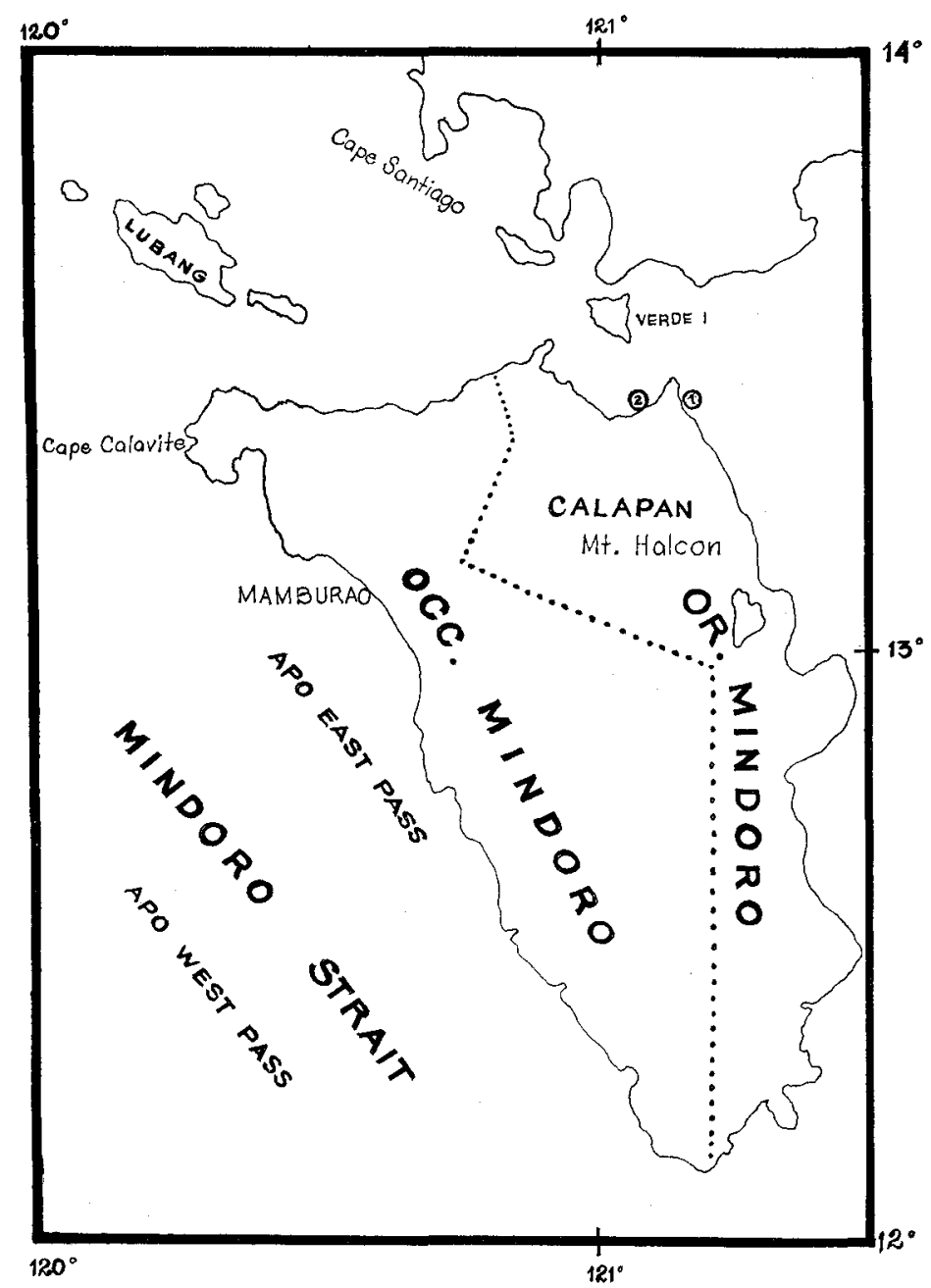

Fig. 1. Collecting stations of A. nana Zanardini in Calapan, Oriental Mindoro: (1) Punta Lazareto, (2) Barangay Balete. 
Punta Lasareto is approximately $3 \mathrm{kms}$ from Calapan town proper. The coast is sandy near the oil depot becoming rocky towards the direction of Calapan town. Boulders, every now and then partly submerged by the incoming tide, fringe the collecting area and on the wet side of the boulders grow thick associations of Acrocystis nana and Bostrychia tenella. Below the Acrocystis-Bostrychia belt are low growths of Gelidiopsis repens, Gracilaria salicornia, Padina japonica and Carpopeltis crispata. Submerged species of Halymenia dilatata, $H$. durvillaei, Polysiphonia sp. compose the intertidal flora.

Barangay Balete, is about $3 \mathrm{kms}$ north-east of the Calapan town proper. Boulders are smaller than those found in Punta Lasareto, but this type of a substratum supports growths of Gelidiella acerosa, Gracilaria eucheumioides, tiny Gelidiopsis repens, Ulva lactuca, Neomeris annulata, few Turbinaria and rhizomes of Sargassum spp. Gracilaria eucheumioides, easily the most dominant alga, forms thick mats on the rocky coast.

\section{Taxonomic Treatment}

Dried materials are kept in the Philippine National Herbarium (PNH), of which voucher specimens will be sent to select Asian, European and American herbaria as exchange plant materials.

The phyco-geographical distribution follows that of Cordero (1977).

\section{Class RHODOPHYCEAE}

Order Ceramiales

Family Rhodomelaceae

Genus Acrocystis Zanardini

Acrocystis nana Zanardini

(Fig. 2)

Okamura 1907: 23, pls. 6 \& 7 Weber-van Bosse 1923: 356; Dawson 1954: 461, fig. 636, C; Segawa 1956: 115, pl. 69, fig. 558; Chihara 1970: 159.

Plants dark purplish-brown, soft, growing in narrow patches in association with Bostrychia tenella. Frond hollow, obovate to ovato-pyriform in outline, borne by short, solid, cylindrical pedicel issued singly or subfasciculately from prostrate rhizome. It reaches $5-6 \mathrm{~mm}$ in height, globose portion averages $2-2.5 \mathrm{~mm}$. Rhizome is barely $0.5 \mathrm{~mm}$ thick, usually branched.

Initially, the plant is appressed to the substrate brought about by the protrusion of hair-like to thickened root-fibers. From the rhizomes arise vertical branches (fronds), the apical portion assuming globose or bulb-shape. The globose structure changes to obovate or pyriform with age. The apex of frond roundish to slightly depressed upon maturity. 


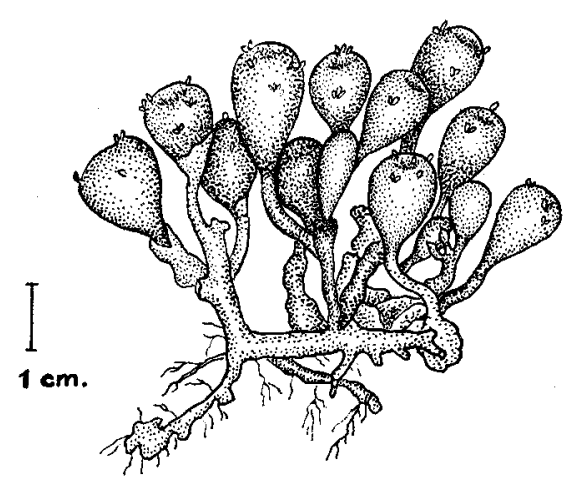

Fig. 2. Habit of $A$, nana Zanardini.

The pedicels are solid and gradually narrowed at the neck portion which together with the rhizome consists of parenchymatic cells in cross-section. Furthermore, the central axis of both vegetative parts are surrounded by 5 pericentral cells, where the heavily packed parenchymatic cells arise. Next to this layer are 1-2 layers of epidermal cells.

Rhizoidal cells arise from the intercellular spaces between the central axis and the pericentral cells as well as outside of the latter.

Descriptive Materials:

North-Western Luzon-ORIENTAL MINDORO, Calapan, Punta Lasareto, PNH 129024; Calapan, Balete, PNH 129025, August 1980. Growing on rocks in association with Bostrychia tenella reached only during extreme high tide.

Remarks:

The Philippine materials are slightly smaller compared to the one reported from Japan which reaches $1 \mathrm{~cm}$ tall, $2-4.5 \mathrm{~mm}$ diameter of the globose structure and $1 \mathrm{~mm}$ thickness of the pedicel.

\section{Acknowledgement}

The author gratefully acknowledges the Philipplne Government through the Philippine National Museum for the continued financial support of the research project; the advance phycology students of UST especially Mrs. Lolita J. Bulalacao who collected the present materials; the Philippine Council for Agriculture and Resources Research through PGARR Project No. 693, for the illustration of the material by Mr. Aurora Magpayo, Scientific Illustractor and Ms. Aurora Quezon, Research-Compiler for typing the manuscript.

\section{LITERATURE CITED}

Chihara, M. 1975. Gakken-Chu-ko Sei (Illustrated Marine algae) 290 p.

Cordero, Jr. P.A. 1977. Studies on Philippine marine red algae. Spec. Publ. Seto Mar. Biol. Lab., Kyoto Univ. ser. IV, 258 p., 28 pls. 266 text-figs. 1 map. 
Dawson, E.Y. 1954. Marine algae in the vicinity of the Institut Oceanographique de Nhatrang, Vietnam, Pac. Sci. 8 (4): 373-469, 63 figs.

Domantay, J. 1961. An ecological survey of the marine vegetation of the Hundred Islands and vicinity. Phil. Jour. Sci. 90: 271-295.

Menez, E.G. 1961. The marine algae of the Hundred Islands. Phil. Jour. Sci. 90: 37-87.

Okamura, K. 1907. Icones of Japanese Algae. Vol. 1, 1-257, pls. 1-50. Tokyo (Published by the author).

Reyes, A.Y. 1971. A survey of the littoral benthic algae of coastal areas of Dumaguete City. Phil. Jour. Sci. 9: 131-163.

Saito, Y. 1967. The algal genus Laurencia from the Hawaiian Islands, the Philippines and adjacent waters. Pac. Sci. 23: 148-159, 11 text-figs.

Segawa, S. 1956. Colored Illustrations of the Seaweeds of Japan. 175 p., 72 pls.

Trono, Jr. G.C. 1974. The marine benthic algae of Siasi Island and vicinity. KALIKASAN, Philipp. J. Biol. 3: 83-97.

Velasquez, G.T., D.F. Cornejo, A.E. Santiago and L.B. Arcega. 1971. Algal communities of exposed and unprotected marine waters of Batangas and Bataan. Phil. Jour. Sci. 100:1-40, 14 pls.

Weber van Bosse, A. 1923. Listes des algues du Siboga. III. Rhodophyceae secund partie, Ceramiales. 3: 311-392. E.J. Brill, Leiden. 